https://doi.org/10.15407/ukrbotj76.01.003

\title{
Artemisia verlotiorum (Asteraceae) in the continental part of Ukraine: now in Kyiv
}

\author{
Sergei L. MOSYAKIN ${ }^{1}$, Ganna V. BOIKO ${ }^{1}$, Svitlana A. GLUKHOVA² \\ ${ }^{1}$ M.G. Kholodny Institute of Botany, National Academy of Sciences of Ukraine \\ 2 Tereschenkivska Str., Kyiv 01004, Ukraine \\ s_mosyakin@hotmail.com \\ bav22@ukr.net \\ ${ }^{2}$ Syrets Arboretum \\ 43 Tyraspolska Str., Kyiv 04136, Ukraine \\ syrets.dendropark@gmail.com
}

Mosyakin S.L., Boiko G.V., Glukhova S.A. 2019. Artemisia verlotiorum (Asteraceae) in the continental part of Ukraine: now in Kyiv. Ukrainian Botanical Journal, 76(1): 3-8.

Abstract. Colonies of Artemisia verlotiorum (Asteraceae), an alien species of East Asian origin now widespread in many countries of the world, were found in 2018 in Kyiv in the Syrets Arboretum (Syretskiy Dendropark) and in a nearby abandoned plant nursery and greenhouses. At present, three clonal colonies have been revealed. Most probably rhizomes of that species were initially introduced to Kyiv with soil and/or imported trees and/or shrubs. However, one colony (along the wall of the administrative building of the arboretum) most probably emerged from seeds dispersed by wind from the main (supposedly initial) colony in the abandoned nursery. Before our find in Kyiv, A. verlotiorum was reliably known in Ukraine in Crimea (reported since the 1920s), Transcarpathia, and from Lviv (recent records, to be discussed in detail in a forthcoming article). Most probably A. verlotiorum is spreading in Eastern Europe mainly by rhizome fragments with soil and plant material. Other alien taxa of the Artemisia vulgaris group (especially $A$. umbrosa and $A$. argyi) occur in Ukraine mainly as "railroad" plants.

Keywords: alien species, Artemisia verlotiorum, Asteraceae, Ukraine

Мосякін С.Л. ${ }^{1}$, Бойко Г.В. ${ }^{1}$, Глухова С.А. ${ }^{2}$ 2019. Artemisia verlotiorum (Asteraceae) у континентальній частині Україні: тепер і в Києві. Український ботанічний журнал, 76(1): 3-8.

${ }^{1}$ Інститут ботаніки ім. М.Г. Холодного НАН України

вул. Терещенківська 2, Київ 01004, Україна

${ }^{2}$ Сирецький дендропарк

вул. Тираспольська 43, Київ 04136, Україна

Реферат. Колонії Artemisia verlotiorum (Asteraceae), виду східноазійського походження, нині натуралізованого у багатьох країнах світу, були знайдені у 2018 році в Києві у Сирецькому дендропарку, а також неподалік нього на території покинутого розплідника рослин і біля теплиць. Виявлені три клональні колонії. Найімовірніше кореневища рослин цього виду спочатку були завезені у Київ з грунтом або імпортованими деревами та кущами. Однак одна колонія (уздовж стіни адміністративної будівлі дендропарку), вірогідно, виникла 3 насіння, занесеного вітром 3 головної (ймовірно первинної) колонії у розпліднику. До нашої знахідки у Києві вид A. verlotiorum був достовірно відомий в Україні з Криму (наводився з 1920-х рр.), Закарпаття та Львова (дані детальніше обговорюватимуться у наступній статті). Найбільш ймовірно, що A. verlotiorum поширюється у Східній Европі переважно фрагментами кореневищ та/ або столонів з грунтом і рослинним матеріалом. Інші адвентивні види групи Artemisia vulgaris (особливо A. umbrosa і A. argyi) трапляються в Україні переважно як "залізничні" рослини.

Ключові слова: чужорідні види, Україна, Artemisia verlotiorum, Asteraceae

\section{Introduction}

Artemisia verlotiorum Lamotte (Asteraceae), a species described from Europe (see Verlot, 1875, 1876; Lamotte, 1877) but native to East Asia (China), is currently known as an alien and/or invasive species naturalized in many

(C) S.L. MOSYAKIN, G.V. BOIKO, S.A. GLUKHOVA, 2019

Український ботанічний журнал, 2019, 76(1) regions of Europe, North and South Africa, western Asia, South America, Australia, and New Zealand (Pampanini, 1923, 1933; Brenan, 1950; Bangerter, 1978; Esler, 1987; Webb et al., 1988; Leonova, 1994; Ariza Espinar, 1997; Thompson, 2007; Ling et al., 2011; Verloove, 2013-onward; Kurşat, Civelek, 2011; Mosyakin et al., 2018, and references therein). It is 
also definitely present in North America (Mosyakin, unpublished data and an article in preparation), where its cryptic invasion was totally overlooked until recently because of its confusion with Eurasian $A$. vulgaris L. s. str. (also introduced in North America), and probably also with some native North American taxa of the A. vulgaris group (Aretmisia sect. Artemisia).

In our earlier articles (Mosyakin, 1990, 1991, 1992, 2006; Dubovik, Mosyakin, 1991; Boiko, 2009, 2012, 2013; Mosyakin et al., 2017, 2018) we already discussed various issues of distribution, morphology, taxonomy and nomenclature of Artemisia verlotiorum, A. umbrosa (Turcz. ex Besser) Turcz. ex Verlot and some other alien species of the $A$. vulgaris species aggregate occurring in Ukraine and other countries of Eastern Europe, in particular, Russia, Belarus, Lithuania, Latvia, etc.

As we already commented (Mosyakin, 1990, 2006; Mosyakin et al., 2018), many earlier records of "A. verlotiorum" from Eastern Europe in fact belong to other related species of the A. vulgaris aggregate, especially $A$. umbrosa and sometimes $A$. argyi H.Lév. $\&$ Vaniot (see discussion and references in Mosyakin et al., 2018).

The specimens of $A$. verlotiorum collected in Kyiv in 2018 (see below) are deposited in the National Herbarium of Ukraine (KW). Herbarium acronyms mentioned in the article follow Thiers (2008-onward).

\section{Earlier records of Artemisia verlotiorum in the territory of Ukraine}

The first known occurrence of $A$. verlotiorum in Ukraine, and in Eastern Europe in general, was reported by Gams (1929) in the 1920s, who mentioned, although with some doubt, that he observed this species as a weed in the Nikita Botanical Garden: "... der Bearbeiter (Gams) konnte sie hier nur im Garten von Nikita auf der Krim als Unkraut feststellen" (Gams, 1929: 631). However, that record was neglected and the species has not been reported in floras and other publications covering the territory of Crimea. This record was confirmed later, first based on observations by Dubovik (see Mosyakin, 1990; Dubovik, Mosyakin, 1991) and then by Mosyakin (2006), who indicated the continued presence of A. verlotiorum in Nikita (Yalta area) in and near the Nikita Botanical Garden. Our analysis (by Boiko) of herbarium specimens of the Nikita Botanical Garden National Science Center (YALT) demonstrated that the species was often collected in this area for many years, but it was misidentified as A. vulgaris (see Boiko, 2009). Special surveys (by Mosyakin and Boiko, before 2014) also demonstrated that $A$. verlotiorum is now widespread in the Crimean South Coast. In particular, we registered this species in Yalta, Gurzuf, Partenit, Koreiz, where in some localities the plants formed dense and large stands (Mosyakin, 2006; Boiko, 2009). At present the species should be considered as fully naturalized in Crimea (at least in the South Coast area).

Artemisia umbrosa (also known under misapplied names "A. codonocephala" auct. non Diels, "A. dubia" auct. non Wall. ex Besser, and "A. lavandulifolia" auct. non DC.; see Mosyakin et al., 2018) is also reported in Crimea (Yena, 2005, 2012; Seregin at al., 2015), but it seems to be much rarer there than $A$. verlotiorum s. str. However, at least some (or most probably all?) records of "A. dubia" by Seregin et al. (2015) in fact belong to A. verlotiorum s. str.; in particular, the following specimens from MW: MW0628959, MW0628960, MW0628961, MW0628962 (images available from Moscow Digital Herbarium: Seregin, 2019). These specimens from Sevastopol and Balaklava correspond to records in the article by Seregin et al. (2015) and because of that the occurrence of A. umbrosa ("A. dubia" sensu auct.) in that area is in need of confirmation.

Cultivation of $A$. verlotiorum by Boiko in the Donetsk Botanical Garden of the National Academy of Sciences of Ukraine in 2005-2014 demonstrated that the plants in this region normally develop numerous vegetative shoots and under favorable conditions reach the flowering and fruiting stages. Because of that it has been suggested that further dispersal of the species in the continental part of Ukraine is quite possible (Boiko, 2009).

Probably the first mention of $A$. verlotiorum for the continental part of Ukraine was made in the editorial note to the article by Boiko (2009: 834): "A. verlotiorum також знайдена, за даними В.В. Протопопової, в м. Ужгороді в палісаднику біля вокзалу; в Чернівецькій обл. поряд із залізницею, поблизу кордону" ("A. verlotiorum was also found, according to V.V. Protopopova, in Uzhgorod in a flower bed [or small garden] near the railway station; in Chernivtsi Region near the railway not far from the [state] border"). That note was added in proof by the editorial team of the Ukrainian Botanical Journal following the personal communication of Prof. Vera V. Protopopova based on observations by and specimens of Protopopova and Myroslav V. Shevera (both from the M.G. Kholodny Institute of Botany). The studied specimens from Transcarpathian Region deposited in $\mathrm{KW}$ evidently belong to $A$. verlotiorum s. str.; however, $A$. umbrosa was also recently found in Transcarpathia by Shevera (personal communication; 

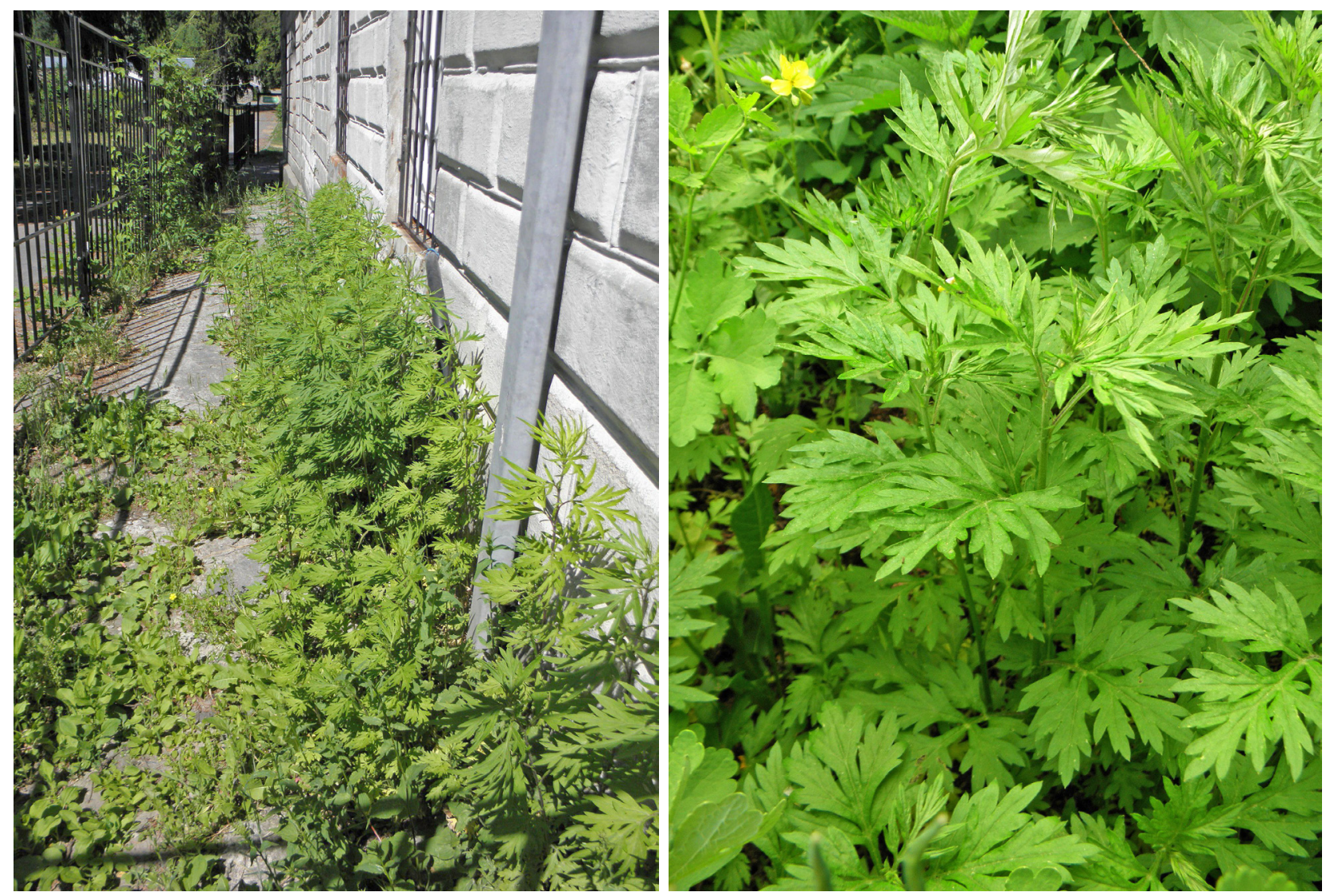

Fig. 1. Artemisia verlotiorum along the wall of the administrative building (left) and in a lilac garden (right, young shoots), Syrets Arboretum, Kyiv (May 2018, all photographs by S. Mosyakin).

Boiko et al., article in preparation). In our opinion, the specimens from Chernivtsi Region available in KW belong to $A$. umbrosa and because of that the presence of A. verlotiorum s. str. in that region cannot be confirmed yet. However, considering the occurrence of the latter in adjacent countries of Eastern Central Europe, finds of A. verlotiorum in Chernivtsi Region cannot be excluded in the future. In addition to that, A. verlotiorum s. str. is now also reported from Lviv (Mamchur et al., 2017), which is also confirmed by some specimens deposited in KW. However, the morphologically similar species A. umbrosa is also known in Lviv Region (Kuzyarin, 2012) and because of that critical revision of specimens and records of $A$. verlotiorum and $A$. umbrosa from the western part of Ukraine is needed, and will be provided in a forthcoming article (Boiko et al., in preparation).

\section{Artemisia verlotiorum in Kyiv}

A colony of $A$. verlotiorum was discovered in Kyiv by Mosyakin on 12 May 2018. The plants were growing in shady places in a lilac garden (syringarium) not

far from the entrance of the Syrets Arboretum (Syretskiy Dendropark, Сирецький дендропарк) in the northwestern part of the city. This species was not mentioned in the recent checklists of plants of the arboretum (Glukhova et al., 2016; Shynder et al., 2018).

Another clonal stand of $A$. verlotiorum was found on 28 May 2018 along the back wall of the administrative building of the arboretum (Fig. 1), where plants were growing in the cracks of asphalt (tarmac) and between the asphalt surface and the brick wall. Growing conditions of this colony suggested that it emerged not from rhizomes/stolons or rhizome fragments but from seeds brought by wind from some other nearby colony. Special surveys in the territory of a nearby abandoned plant nursery revealed a larger colony near destroyed greenhouses and along the road (Fig. 2,3). Most probably that colony was the source of seeds that produced the two smaller colonies in the Syrets Arboretum, especially the stands along the wall (see above).

Our observations in August-October of 2018 confirmed that in climatic conditions of Kyiv (as

Український ботанічний журнал, 2019, 76(1) 


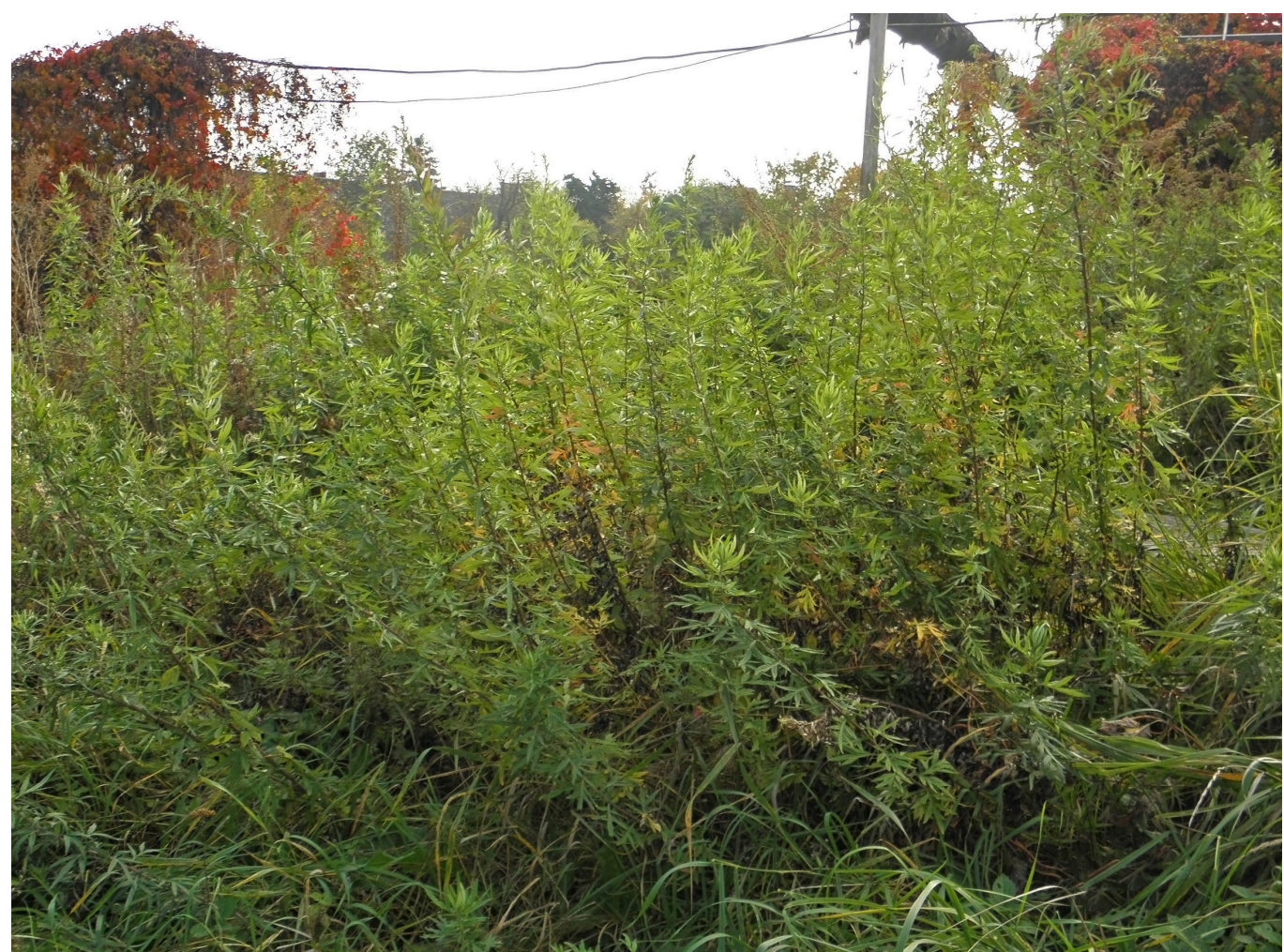

Fig. 2. Dense stands of Artemisia verlotiorum in an abandoned plant nursery near the Syrets Arboretum, Kyiv (October 2018)
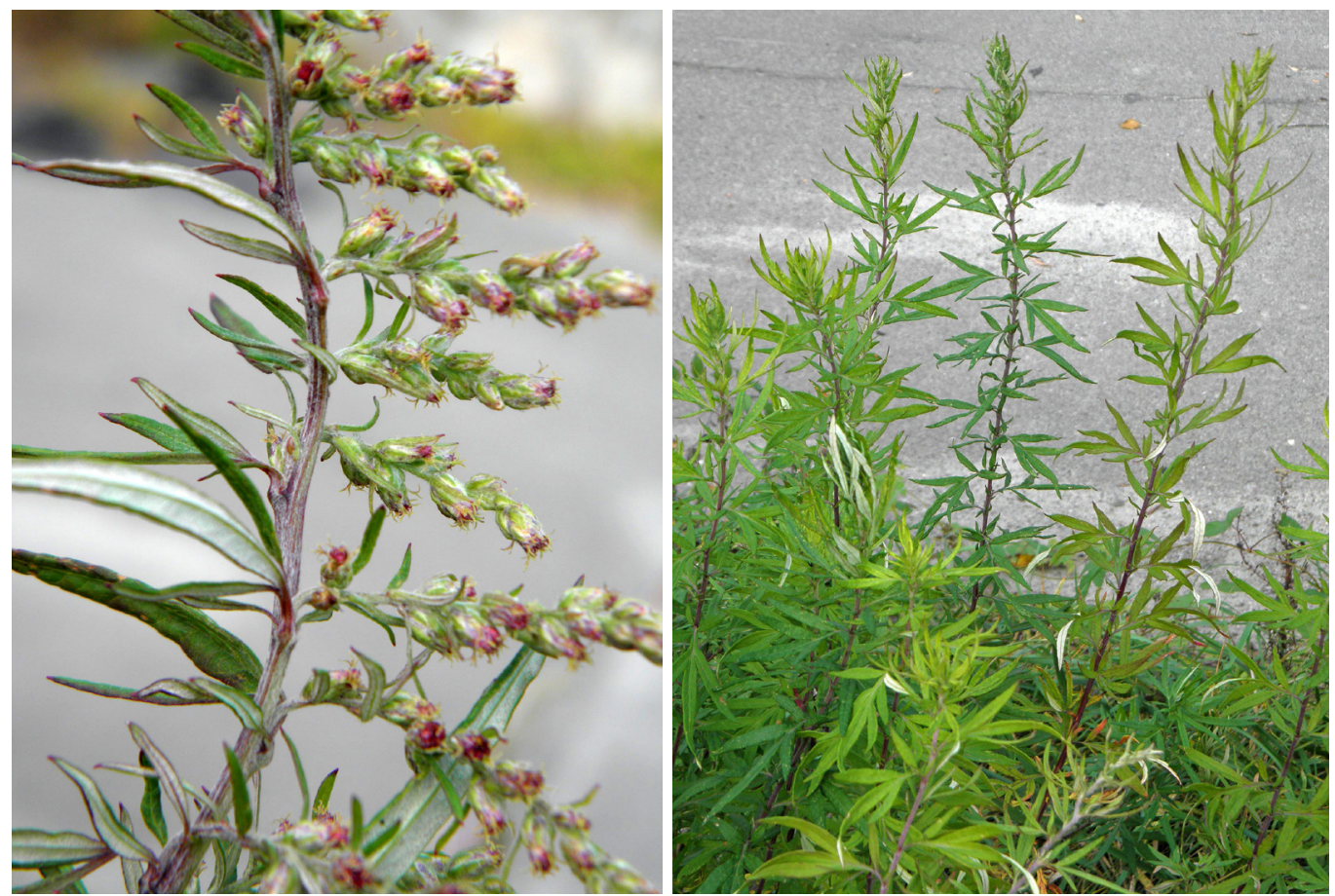

Fig. 3. Artemisia verlotiorum growing along the road in an abandoned plant nursery near the Syrets Arboretum, Kyiv (October, 2018) 
well as elsewhere within its native and introduced range) $A$. verlotiorum is a very late-flowering species, especially if compared to $A$. vulgaris s. str. The shoots of $A$. verlotiorum were rather well developed already in mid-May (see Fig. 1); however, first inflorescences were observed in the Syrets Arboretum in late August, and only in October the plants started to produce seeds. At that time the plants of $A$. vulgaris growing nearby were fully developed and already abundantly produced ripe seeds since mid-summer.

The plants were growing in ruderal plant communities together with the following common associated species: Artemisia vulgaris, Ballota nigra L. aggr. (incl. B. ruderalis Sw.), Elytrigia repens (L.) Nevsky (Elymus repens (L.) Gould), Erigeron canadensis L. (Conyza canadensis (L.) Cronquist), Humulus lupulus L., Parthenocissus inserta (A.Kern.) Fritsch, Solidago canadensis L., Urtica dioica L., with lesser participation of Atriplex sagittata Borkh., Chelidonium majus L., Chenopodium album L. aggr., C. betaceum Andrz. (C. strictum auct. non Roth), Fallopia convolvulus (L.) Á.Löve, Lactuca serriola L., Oenotera biennis L. aggr., etc.

\section{Concluding remarks}

The actual distribution patterns of Artemisia verlotiorum in Eastern Europe are obscured by earlier misidentifications because that species is morphologically similar to and so easily confused with other taxa of the $A$. vulgaris aggregate, especially $A$. umbrosa. As we discussed above, there were also some cases of misidentification of Ukrainian specimens from the continental and peninsular (Crimea) parts of the country.

We expect that $A$. verlotiorum s. str. will be found in the future in some other regions of Ukraine, especially in parks, botanical gardens, and other similar habitats to which the rhizomes of this species can be brought with soil or plant material. However, occurrence and dispersal of $A$. verlotiorum along railroads, roads, river valleys, etc., is also possible.

\section{Acknowledgments}

We are grateful to Vera V. Protopopova and Myroslav V. Shevera (M.G. Kholodny Institute of Botany, NAS of Ukraine) for providing information on the occurrence of A. verlotiorum in the Transcarpathian Region and Lviv, to Zvenislava I. Mamchur and Maria V. Chuba (Ivan Franko National University of Lviv) for providing images of plants from Lviv, and to Filip Verloove (Botanic Garden Meise, Belgium) and Peter J. de Lange (Environment and Animal Sciences, UniTec Institute of Technology, Auckland, New Zealand) for their useful comments on the manuscript.

\section{REFERENCES}

Ariza Espinar L. 1997. Anthemideae. In: Flora fanerogámica Argentina. Fasc. 46: Asteraceae, pt. 7. Córdoba, Argentina: Programa ProFlora (CONICET), 33 pp.

Bangerter E.B. 1978. New and interesting records of adventive plants from the Auckland Institute and Museum Herbarium. Records of the Auckland Institute and Museum, 15: 27-35.

Boiko G.V. 2009. New data on alien species of the genus Artemisia L. (Asteraceae) in the Ukrainian flora. Ukrainian Botanical Journal. 66(6): 833-835. [Бойко Г.В. 2009. Нові відомості щодо адвентивних видів з роду Artemisia L. (Asteraceae) флори України. Український ботанічний журнал, 66(6): 833-835].

Boiko A.V. [G.V.]. 2012. Artemisia umbrosa (Turcz. ex Besser) Pamp., an alien species in the flora of Ukraine. In: Problemy izucheniya adventivnoy i sinantropnoy flor Rossii i stran blizhnego zarubezhya: 4 Mezhdunarodnaya konferentsiya (Izhevsk, 4-7 Dec. 2012 g.). Eds O.G. Baranova, A.N. Puzyrev. Izhevsk, pp. 27-29. [Бойко А.B. 2012. Artemisia umbrosa (Turcz. ex Besser) Pamp. - адвентивный вид флоры Украины. В сб.: Проблемы изучения адвентивной и синантропной флор России и стран ближнего зарубежья: 4 международная конференция (Ижевск, 4-7 декабря 2012 г.). Ред. О.Г. Баранова, А.Н. Пузырев. Ижевск, с. 27-29].

Boiko G.V. 2013. Identification key for the species of the genus Artemisia L. (Asteraceae) of the flora of Ukraine. Ukrainian Botanical Journal, 70(4): 479-482. [Бойко Г.В. 2013. Ключ для визначення видів роду Artemisia L. (Asteraceae) флори України. Український ботанічний журнал, 70(4): 479-482].

Brenan J.P.M. 1950. Artemisia verlotorum Lamotte and its occurrence in Britain. Watsonia, 1(4): 209-223.

Dubovik O.N., Mosyakin S.L. 1991. Artemisia verlotiorum (Asteraceae) - a new adventive species of the North Caucasus flora. Botanicheskii Zhurnal, 76(10): 14081411. [Дубовик О.Н., Мосякин С.Л. 1991. Artemisia verlotiorum (Asteraceae) - новый адвентивный вид флоры Северного Кавказа. Ботанический журнал, 76(10): 1408-1411].

Esler A.E. 1987. The naturalisation of plants in urban Auckland, New Zealand 3. Catalogue of naturalised species. New Zealand Journal of Botany, 25: 539-558. https://doi.org/10.1080/0028825X.1987.10410085

Gams H. 1929. Artemisia. In: Hegi G. Illustrierte Flora von Mitteleuropa, Bd 6, Hf 2. München: Verlag J.F. Lehmann, S. 626-672.

Glukhova S.A., Shynder O.I., Yemets L.I., Mykhaylyk S.M. 2016. Catalogue of herbaceous plants of the Syretskiy Arboretum. Poltava: Poltavskiy Literator, 82 pр. [Глухова С.А., Шиндер О.І., Ємець Л.І., Михайлик С.М. 2016. Каталог трав'янистих рослин Сирецького дендрологічного парку. Полтава: Полтавський літератор, $82 \mathrm{c.}$.

Kurşat M., Civelek Ş. 2011. Artemisia vulgaris L. ve Artemisia verlotiorum Lamotte (Asteraceae) Türlerinin Morfolojik Bakımından Araștırılması (Morphological investigation of Artemisia vulgaris L. and Artemisia verlotiorum 
Lamotte species). Firat Üniversites Fen Bilimleri Dergisi, 23(2): 125-132.

Kuzyarin O.T. 2012. Alien species of vascular plants new for Lviv Region. Naukovi Zapysky Derzhavnogo Pryrodoznavchogo Миzеуu (Lviv), 28: 143-144. [Кузярін О.Т. 2012. Нові адвентивні види судинних рослин для Львівської області. Наукові записки Державного природознавчого музею (Львів), 28: 143-144].

Lamotte M. 1877. Recherches sur une nouvelle espèce du genre Artemisia. Compte-Rendu de l'Association Française pour l'Avancement des Sciences, Paris (Compte-Rendu de la $5^{\mathrm{me}}$ Session. Clermont-Ferrand, 1876), 5: 511-513.

Leonova T.G. 1994. Artemisia. In: Flora Partis Europaeae URSS, vol. 7. Ed. N.N. Tzvelev. Leningrad: Nauka, pp. 150-174. [Леонова Т.Г. 1994. Artemisia. В кн.: Флора европейской части СССР, т. 7. Ред. Н.Н. Цвелев. Ленинград: Наука, с. 150-174].

Ling Y.-R., Humphries C.J., Gilbert M.G. 2011. Artemisia. In: Flora of China, vol. 20-21. Eds Z.Y. Wu, P.H. Raven, D.Y. Hong. Beijing: Science Press \& St. Louis: Missouri Botanical Garden Press, pp. 676-737.

Mamchur Z., Chuba M., Drach Yu. 2017. Bryophytes and vascular plants in railway areas of the city of Lviv. Visnyk Lvivs'kogo Universytetu. Series Biology, 75: 54-65. [Мамчур 3., Чуба М., Драч Ю. 2017. Мохоподібні та судинні рослини на території залізниці міста Львова. Вісник Львівського університету. Серія біологічна, 75: 54-65].

Mosyakin S.L. 1990. New and noteworthy alien species of Artemisia L. (Asteraceae) in the Ukrainian SSR. Ukrainian Botanical Journal, 47(4): 10-13.

Mosyakin S.L. 1991. Preliminary list of recent additions to the alien flora of Ukraine. Ukrainian Botanical Journal, 48(4): 28-34.

Mosyakin S.L. 1992. Floristic notes on alien plants in Kiev. Ukrainian Botanical Journal, 49(6): 36-39. [Мосякін С.Л. 1992. Флористичні нотатки про адвентивні рослини м. Києва. Український ботанічний жжрннал, 49(6): 36-39].

Mosyakin S.L. 2006. On distribution of Artemisia verlotiorum Lamotte (Asteraceae) and related alien species in Ukraine. Chornomors'kyi Botanichnyi Zhurnal, 2(1): 93-97. [Мосякін С.Л. 2006. До поширення Artemisia verlotiorum Lamotte (Asteraceae) та споріднених адвентивних видів в Україні. Чорноморський ботанічний журнал, 2(1): 93-97].

Mosyakin S.L., Boiko G.V., Verloove F. 2017. Lectotypification of Artemisia mongolica $(=A$. vulgaris var. mongolica, Asteraceae). Phytotaxa, 297(3): 257-264. https://doi.org/10.11646/phytotaxa.297.3.4

Mosyakin S.L., Verloove F., Boiko G.V. 2018. The correct authorship and nomenclature of Artemisia umbrosa (Asteraceae), with comments on some misapplied names and distribution of the species in Eastern Europe. Ukrainian Botanical Journal, 75(3): 213-229. https://doi.org/10.15407/ukrbotj75.03.238

Pampanini R. 1923. Contributo alla conoscenza dell' Artemisia Verlotorum Lamotte. Bullettino della Società Botanica Italiana [vol. of 1923], 1-2: 76-90.
Pampanini R. 1933. Settimo ed ultimo contributo alla conoscenza dell' "Artemisia Verlotorum" Lamotte. Nuovo Giornale Botanico Italiano, n. s., 40(2): 183-224.

Seregin A.P. (Ed.). 2019. Moscow Digital Herbarium: Electronic resource. Moscow: Moscow State University. Available from: https://plant.depo.msu.ru (Accessed 02 February 2019).

Seregin A.P., Yevseyenkov P.E., Svirin S.A., Fateryga A.V. 2015. Second contribution to the vascular flora of the Sevastopol area (the Crimea). Wulfenia, 22: 33-82.

Shynder O.I., Glukhova S.A., Mykhaylyk S.M. 2018. Spontaneous flora of the Syrets Arboretum of the national importance (city of Kyiv). Introduktsiya Roslyn (Kyiv), 2: 54-63. [Шиндер O.I., Глухова С.А., Михайлик С.М. 2018. Спонтанна флора Сирецького дендрологічного парку загальнодержавного значення (м. Київ). Інтродукція рослин (Київ), 2: 54-63].

Thiers B. 2008-onward (continuously updated). Index Herbariorum. A global directory of public herbaria and associated staff. New York Botanical Garden's Virtual Herbarium. Available from: http://sweetgum.nybg.org/ science/ih (Accessed 02 February 2019).

Thompson I.R. 2007. A taxonomic treatment of tribe Anthemideae (Asteraceae) in Australia. Muelleria, 25: 21-58.

Verloove F. 2013-onward. Not every Far Eastern mugwort is Artemisia verlotiorum! In: Verloove F. Manual of the Alien Plants of Belgium. Botanic Garden of Meise, Belgium. Available from: http://alienplantsbelgium.be/content/ not-every-far-eastern-mugwort-artemisia-verlotiorum (Accessed 02 February 2019).

Verlot J.-B. 1875. Catalogue des graines du Jardin botanique de Grenoble, 1875. Grenoble [non vidi].

Verlot J.-B. 1876. Artemisia umbrosa Turcz. [Note extraite du Catalogue des graines du Jardin botanique de Grenoble, 1875, par M. J.-B. Verlot]. P. 73 in: [Anonymous]. Notes sur quelques espèces distribuées cette année [1876]. Bulletin de la Société Dauphinoise pour l'Échange des Plantes [Première série de 1874 à 1889], 3: 69-84.

Webb C.J., Sykes W.R., Garnock-Jones P.J. 1988. Flora of New Zealand, vol. 4. Christchurch: Botany Division, Department of Scientific and Industrial Research (DSIR), lxviii + 1365 pp.

Yena A.V. 2005. Artemisia codonocephala. In: Greuter W., von Raab-Straube E. (Eds). Euro+Med Notulae, 1. Willdenowia, 35: 223-239.

Yena A.V. 2012. Spontaneous flora of the Crimean Peninsula. Simferopol: N. Orianda, 232 pp. [Ена A.В. 2012. Природная флора Крымского полуострова. Симферополь: Н. Оріанда, 232 с.].

Recommended for publication by

Submitted 23.01.2019 F. Verloove 